\title{
Asbestos Fibers and Ferruginous Bodies Detected by VP-SEM/EDS in Colon Tissues of a Patient Affected by Colon-Rectum Cancer: A Case Study
}

\author{
Caterina Rinaudo ${ }^{1, *} \mathbb{\infty}$, Alessandro Croce ${ }^{1} \mathbb{D}$, Stefania Erra ${ }^{2}$, Elisabetta Nada ${ }^{3}$, Marinella Bertolotti ${ }^{4}$, \\ Federica Grosso ${ }^{5}$, Antonio Maconi ${ }^{4}$ and Marco Amisano ${ }^{3}$ \\ 1 Department of Science and Technological Innovation, University of Eastern Piedmont, Viale T. Michel 11, \\ 15121 Alessandria, Italy; alessandro.croce@uniupo.it \\ 2 Department of Anatomy and Pathology, S. Spirito Hospital, Viale Giolitti 2, 15033 Casale Monferrato, Italy; \\ serra@aslal.it \\ 3 Department of General Surgery, S. Spirito Hospital, Viale Giolitti 2, 15033 Casale Monferrato, Italy; \\ enada@aslal.it (E.N.); mamisano@aslal.it (M.A.) \\ 4 Infrastruttura Ricerca Formazione Innovazione, Dipartimento Attività Integrate Ricerca Innovazione, \\ Azienda Ospedaliera SS Antonio e Biagio e Cesare Arrigo, Via Venezia 16, 15121 Alessandria, Italy; \\ mbertolotti@ospedale.al.it (M.B.); amaconi@ospedale.al.it (A.M.) \\ 5 Mesothelioma Unit, Oncology, SS Antonio e Biagio e Cesare Arrigo, General Hospital, Via Venezia 16, \\ 15121 Alessandria, Italy; federica.grosso@ospedale.al.it \\ * Correspondence: caterina.rinaudo@uniupo.it
}

Citation: Rinaudo, C.; Croce, A.; Erra, S.; Nada, E.; Bertolotti, M.; Grosso, F.; Maconi, A.; Amisano, M. Asbestos Fibers and Ferruginous Bodies Detected by VP-SEM/EDS in Colon Tissues of a Patient Affected by Colon-Rectum Cancer: A Case Study. Minerals 2021, 11, 658. https: / / doi.org/10.3390/ $\min 11060658$

Academic Editors: Michele Mattioli and Matteo Giordani

Received: 24 May 2021

Accepted: 17 June 2021

Published: 21 June 2021

Publisher's Note: MDPI stays neutra with regard to jurisdictional claims in published maps and institutional affiliations.

Copyright: (c) 2021 by the authors. Licensee MDPI, Basel, Switzerland. This article is an open access article distributed under the terms and conditions of the Creative Commons Attribution (CC BY) license (https:// creativecommons.org/licenses/by/ $4.0 /)$.

\begin{abstract}
The aim of this work was to inspect the presence of asbestos fibers in colon tissue from a patient, with history of indirect exposure to asbestos and affected by colon cancer, who underwent surgery. Variable pressure scanning electron microscopy, coupled with energy dispersive spectroscopy (VP-SEM/EDS), was used for identification of inorganic fibers and for their morphologicalchemical characterization. Fresh tissue samples from both, healthy area close to the neoplasia and from the neoplastic regions, were separately digested to eliminate the biological matrix. The precipitate was analyzed by VP-SEM/EDS, identifying in samples from healthy tissue asbestos bodies and small asbestos fibers, and in samples from neoplastic tissue long fibers of asbestos, free from covering. A quantification of the asbestos bodies and the free fibers in the two type of specimens is proposed. Moreover, to locate the fibers in the biological medium, histological sections from the colon of the same patient were also examined. Free asbestos fibers appeared concentrated in the tissue bridge between the healthy and the neoplastic areas. Immuno-histochemical investigation performed on the neoplasia seems to exclude a role of microsatellite instability in the carcinogenesis process, suggesting an influence of the fibers.
\end{abstract}

Keywords: asbestos; ferruginous bodies; colon cancers; VP-SEM/EDS

\section{Introduction}

Among the minerals regulated as "asbestos" five belong to the amphibole group (actinolite, $\mathrm{Ca}_{2}\left(\mathrm{Mg}, \mathrm{Fe}^{2+}\right)_{5}\left[\mathrm{Si}_{8} \mathrm{O}_{22}\right](\mathrm{OH})_{2}$; amosite, $\left(\mathrm{Fe}^{2+}, \mathrm{Mg}\right)_{7}\left[\mathrm{Si}_{8} \mathrm{O}_{22}\right](\mathrm{OH})_{2}$; anthophyllite, $\left(\mathrm{Mg}_{3} \mathrm{Fe}^{2+}\right)_{7}\left[\mathrm{Si}_{8} \mathrm{O}_{22}\right](\mathrm{OH})_{2} ;$ crocidolite, $\mathrm{Na}_{2} \mathrm{Fe}^{2+}{ }_{3} \mathrm{Fe}^{3+}{ }_{2}\left[\mathrm{Si}_{8} \mathrm{O}_{22}\right](\mathrm{OH})_{2}$; and tremolite, $\left.\mathrm{Ca}_{2} \mathrm{Mg}_{5}\left[\mathrm{Si}_{8} \mathrm{O}_{22}\right](\mathrm{OH})_{2}\right)$. They are classified as "asbestos" when they exhibit fibrous habit. Another phase belongs to the phyllosilicates, in particular to the serpentines, and it is chrysotile $\left(\mathrm{Mg}_{3} \mathrm{Si}_{2} \mathrm{O}_{5}(\mathrm{OH})_{4}\right)$. It must be emphasized that the reported chemical formulae are the theoretical ones, because to the fact that, growing in natural environment, chemical substitutions in the different crystallographic sites frequently occur [1].

A strong correlation between inhaled fibers of these minerals and the development of severe respiratory diseases, such as malignant pleural mesothelioma, pulmonary carcinoma and asbestosis, has been demonstrated in multiple reports [1-9]. Moreover, several recent 
studies described the presence of asbestos fibers in the gallbladder and in the liver of patients with severe diseases in the upper part of the gastro-intestinal system or with cholangiocarcinoma [10-13]. On the other hand, the relationship between cancers of laryngeal and ovarian peritoneum and asbestos has also been recognized by the IARC [14], but the correlation between asbestos and gastrointestinal cancers has not been completely clarified [15].

The identification of asbestos fibers in the neoplastic tissues, or near to these, may provide evidence for consider the relevance of studies about their role in the development of the diseases also in extra-pulmonary tissues. This type of studies is particularly significant in populations exposed to asbestos, through the environment or because of work.

Few studies have been conducted on the presence of asbestos in colon-rectum [16-18]. Therefore, here we examined whether asbestos fibers could be identified in colon-rectum tissues of patients, directly or indirectly exposed to asbestos.

Using variable pressure scanning electron microscopy (VP-SEM), coupled with energy dispersive spectroscopy (EDS), samples of colon-rectum tissues from a patient with indirect exposure to asbestos and affected by colon cancer have been examined. Fresh samples from surgically obtained neoplastic tissues and from healthy areas near the neoplasia were separately prepared. The biological component was removed by digestion and the number of the asbestos fibers per gram of tissue was determined (ff/g). In parallel, histological sections from colon tissues of the same patient were examined under VP-SEM/EDS to localize the fibers in the biological medium. To inspect about the potential molecular mechanism involved in colon carcinogenesis in the studied case, mismatch repair protein expression, B-RAF V600E mutation and RAS gene status, were determined.

\section{Materials and Methods}

This study included a patient, indirectly exposed to asbestos and affected by colonneoplasia anonymized by pathologists. Approximately $0.5 \mathrm{~g}$ of colon-rectum tissue was surgically obtained and weighed using a technical balance (BC1000, OrmaEurotek, Milan, Italy), working with an instrumental error of $\mathrm{d}=1 \times 10^{-2} \mathrm{~g}$. The organic component was removed by digestion with $30 \mathrm{~mL}$ of $\mathrm{NaClO}$ (12.5\%; Carlo Erba, Cornaredo, MI, Italy) and heating the solution to $60{ }^{\circ} \mathrm{C}$. The solution was filtered on a mixed polycarbonate filter, with a porosity $0.2 \mu \mathrm{m}$ and diameter of $25 \mathrm{~mm}$, to collect the inorganic material. In order to reduce precipitation of foreign material, in particular $\mathrm{NaCl}$, during the filtration process the solution was diluted using MilliQ water, heated at $60{ }^{\circ} \mathrm{C}$.

The filters were examined using VP-SEM with an ESEM Quanta 200 (FEI Company, Hillsboro, OR, USA), equipped with an energy dispersive spectroscopy (EDS, EDAX, Mahwah, NJ, USA) microprobe and a back-scattered electron detector. The experimental conditions were set as follows: pressure of $90 \mathrm{~Pa}$, working distance of $10 \mathrm{~mm}$ and accelerating voltage of $20 \mathrm{kV} .650$ microscopic fields, corresponding to approximately $12 \mathrm{~mm}^{2}$, were analyzed at a magnification of $2000 \times$. The microscopic fields displayed along six parallel horizontal strips, and the distance between the horizontal strips was previously defined to avoid overlap between the examined areas. The back-scattered images, characterized by white/black contrast produced by inorganic material, allowed easy detection of the inorganic phases, as described in previous works $[10,11]$. Detailed morphological characterization of the fibers-including length, thickness and length/thickness $(1 / \mathrm{t})$ ratio-was performed using Image J software; the error in data was estimated in $\pm 0.02 \mu \mathrm{m}$. The EDS spectra were processed using GENESIS software, version 3.6. For each fibrous morphology, the elemental composition was assessed by several microanalyses on the inorganic phases (analyses IN) and on the areas close to them (analyses OUT), then performing the difference between the mean values obtained in IN and OUT analyses. Being the EDS chemical analyses carried out directly on the observed fibrous phases, and being the sample not polished and not conductive, the obtained values must be considered qualitative. Nevertheless, the identification of the mineral phase was confirmed by comparison with the EDS spectra database acquired in our laboratories on pure samples of the 
different asbestos phases [19-22], re-analyzed under VP-SEM/EDS under the above cited experimental conditions.

In parallel, three 5- $\mu$ m-thick non-stained sections from paraffin-embedded blocks were prepared for VP-SEM/EDS analysis. The sections were prepared on plastic slides, as described previously $[10,11,13,23]$, which are free from interference with the chemicals constituting the asbestos minerals-i.e., $\mathrm{Si}, \mathrm{Mg}, \mathrm{Na}, \mathrm{Fe}, \mathrm{Ca}$. Therefore, any detected chemical elements were attributable to the observed inorganic phases. Before analysis by VP-SEM/EDS, the $5-\mu \mathrm{m}$-thick sections were placed in an oven at $60^{\circ} \mathrm{C}$ overnight to reduce the paraffin film.

One section was also prepared on glass and stained with hematoxylin-eosin for microscopic observation by pathologist. The section was placed in an oven at $60{ }^{\circ} \mathrm{C}$ overnight to reduce the paraffin film, de-paraffinized with xylene and an alcohol gradient and then rehydrated in $\mathrm{H}_{2} \mathrm{O}$. The sections were then processed using the SEKURA system (BioOptica, Milan, Italy).

Immunohistochemical analyses using MLH1, PMS2, MSH6, MSH2 and BRAF V600E Ventana monoclonal anti-bodies were performed using VentanaOptiView. RAS mutations were detected in paraffin-embedded tumor samples through PCR at the molecular diagnostic laboratory, sited in surgical pathology of Alessandria hospital, an accredited reference structure.

\section{Results}

At first, we discuss the results from fresh tissues, which, as specified before, were samples from areas near to the neoplasia-healthy tissues—and from neoplastic tissues, separately prepared and studied.

\subsection{Healthy Tissues}

$0.55 \mathrm{~g}$ of tissue in the healthy areas neighboring to the neoplasia were digested and the precipitate analyzed under VP-SEM/EDS. The experiment was replicated and the two obtained filters studied. In Figure 1a, a long fiber, observed in one sample under VPSEM/EDS, is shown. The morphological characteristics of the fiber were: $25 \mu \mathrm{m}$ in length, $0.3 \mu \mathrm{m}$ in thickness and $1 / \mathrm{t}$ ratio = approximately 83 . According to the $\mathrm{WHO}$ definition, these characteristics classify the fiber as "breathable" [24]. On the central region of the fiber a process of recovering by material appearing as pearls around the elongated crystal was evident; these pearls appeared brighter on the backscattered (BS) images and leaving small, non-recovered, portions among different rounded formations. This is a well-known mechanism, producing the "asbestos bodies", often detected around the longest fibers in the tissues of the respiratory system and considered markers for exposure to asbestos. The covering is made by iron-proteins, affecting parts or the whole fiber, and it constitutes a way to isolate the foreign material from the biological medium $[25,26]$. In the fiber shown in Figure 1a, the covering process is at a first step, being evident and well-formed only in the central part of the long fiber. The chemical characterization was performed recording at first an EDS spectrum in the area exterior to the fiber (analysis OUT), corresponding to point 1 on Figure 1a. Only peaks for $\mathrm{Na}$ and $\mathrm{Cl}$, which are components of the solution used for digestion, were detected (Figure 1b). This result indicates that during the filtration process $\mathrm{NaCl}$ can precipitate.

Directing after the electron beam onto the fiber of Figure 1a, typical EDS spectra recorded on covered (point 2) and non-covered (point 3) parts are shown, respectively, in Figure $1 \mathrm{c}$,d. Considering the $\mathrm{Na}$ and $\mathrm{Cl}$ peaks ascribed to $\mathrm{NaCl}$, as demonstrated by the OUT spectrum in Figure $1 \mathrm{~b}$, the peaks assigned to $\mathrm{Si}, \mathrm{Fe}$ and $\mathrm{Mg}$, in order of decreasing intensities, were surely produced by the fiber. Superimposing now the two spectra of Figure 1c,d, as described in Croce et al., 2013 [23], Figure 1e, the difference between the two spectra appeared in higher amount of Fe in the EDS spectrum from covered part of the fiber-black spectrum in Figure 1e. This result is consistent with the fact that the fiber covering is made by iron-proteins. The detected chemicals and the relative intensities of 
the corresponding peaks, allowed to propose "amosite", the commercial term for grunerite, and defined "asbestos", as mineral phase, see above.
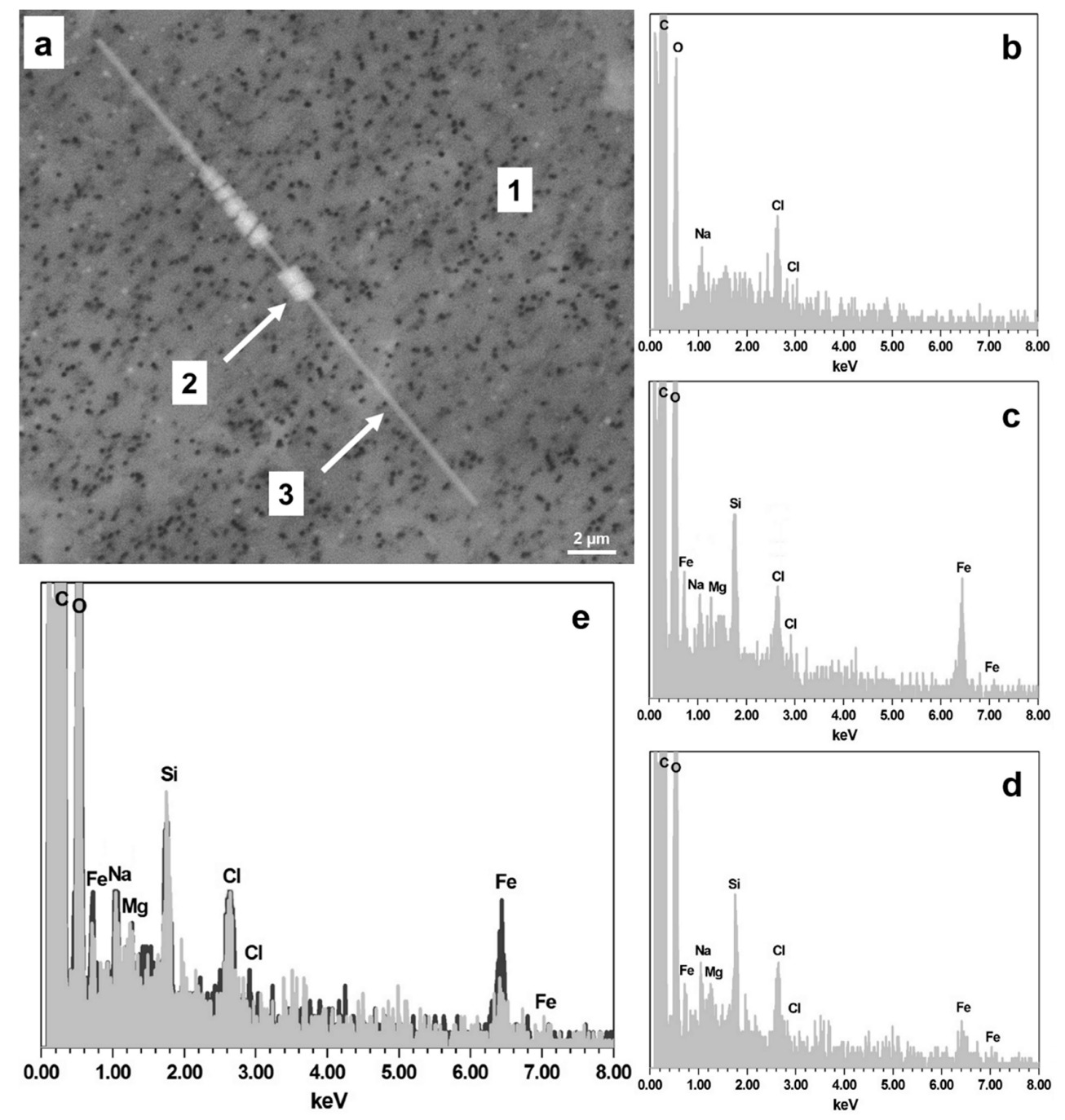

Figure 1. Asbestos body observed in digested healthy tissue and EDS analyses. (a) Asbestos body observed in the healthy tissue. (b) EDS spectrum recorded in the region labeled " 1 " on (a), far from the asbestos body. $\mathrm{Na}$ and $\mathrm{Cl}$ are the only detected ions, due to $\mathrm{NaCl}$ crystallization during the digestion process. (c) EDS spectrum recorded in the region labeled "2" on (a), corresponding to the covered part of the fiber. (d) EDS spectrum recorded in the region labeled " 3 " on (a), representing the part of the fiber free from the covering. (e) Superimposition of the EDS spectra in (c,d), showing that the fiber is composed of $\mathrm{Si}, \mathrm{Fe}$ and $\mathrm{Mg}$, with relative intensities leading to the identification of amosite.

Also elongated crystals, as that shown in Figure 2a, have been observed. Considering the $\mathrm{Na}$ and $\mathrm{Cl}$ peaks due to $\mathrm{NaCl}$ precipitation during the filtration process, the peaks of $\mathrm{Si}, \mathrm{Mg}, \mathrm{Ca}$, and Fe can be ascribed to the fiber. Remembering that the EDS analyses must be considered only qualitative due to the experimental setup, the chemical elements and the relative intensities of the corresponding peaks lead to identify tremolite/actinolite, both regulated as asbestos. These fibers are shorter than those defined as "breathable" by WHO [24] - about $3.5 \mu \mathrm{m}$ vs. $\geq 5 \mu \mathrm{m}$ in length, thickness about $0.5 \mu \mathrm{m}$ and $1 / \mathrm{t}$ ratio of approximately 7.5-but, being detected out of the respiratory system, they have been considered in the counting. To quantify now the number of fibers or asbestos bodies in the analyzed tissues, we used the equation proposed by Belluso et al., [27]: 
and a number of fibers (ff) or asbestos bodies per wet tissue $(\mathrm{g})$ of about $3 \times 10^{3} \mathrm{ff} / \mathrm{g}$ has been calculated.
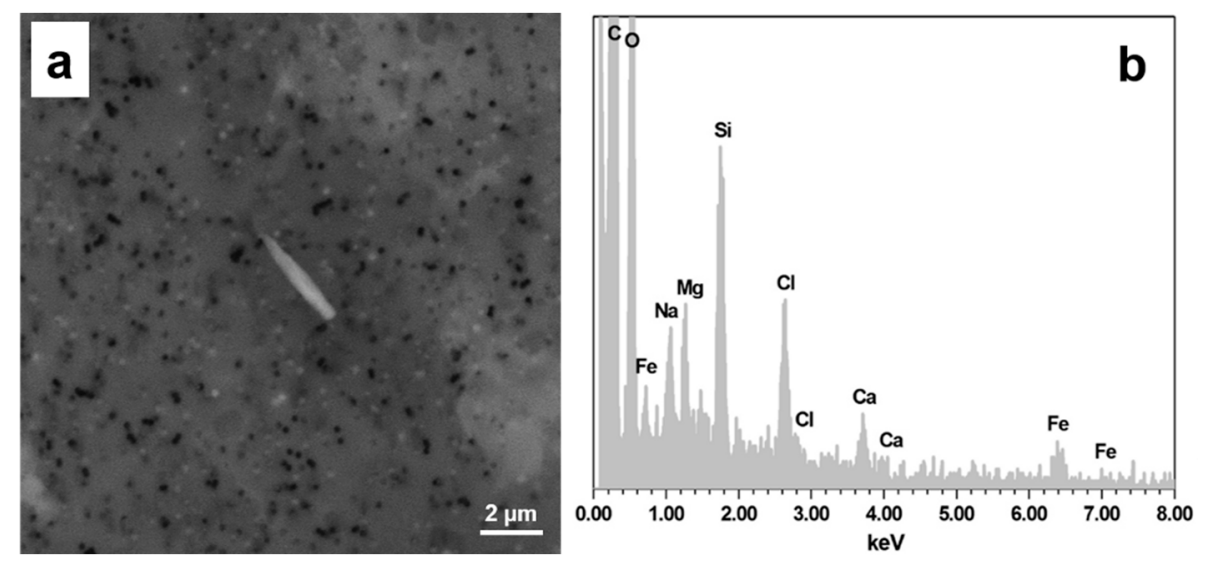

Figure 2. Free fiber observed in digested healthy tissue and relative EDS analysis. (a) Small fiber observed in the healthy tissue. (b) EDS spectrum acquired on the fiber in (a); the chemicals and the relative intensities of the peaks identify tremolite/actinolite, minerals regulated as asbestos. Na and $\mathrm{Cl}$ peaks are ascribed to $\mathrm{NaCl}$ crystallization during the digestion process.

\subsection{Neoplastic Tissue}

In the precipitate after digestion of the neoplastic tissue VP-SEM/EDS did not reveal fibers covered by iron-proteins, as those previously described and forming the "asbestos bodies", but revealed long 20-50 $\mu \mathrm{m}$ bundles of free fibers (Figure $3 \mathrm{a}, \mathrm{b}$ ) or long individual fibers (Figure 3c). The EDS spectrum for all crystals is represented in Figure 4a. We superimposed the EDS spectra from the fiber/bundle of fibers (Figure 4a) with that obtained on the surrounding area, shown in Figure $4 \mathrm{~b}$, and $\mathrm{Si}$ and $\mathrm{Mg}$ appeared as constituting chemical elements. The morphological characteristics of the fibers, their flexibility and the splitting of the thick bundle of fibers into more thin fibrils, Figure $3 b$, and the relative intensities of the Si and Mg peaks on the EDS spectra led to the identification of chrysotile, the serpentine mineral phase regulated as asbestos $[14,24]$.
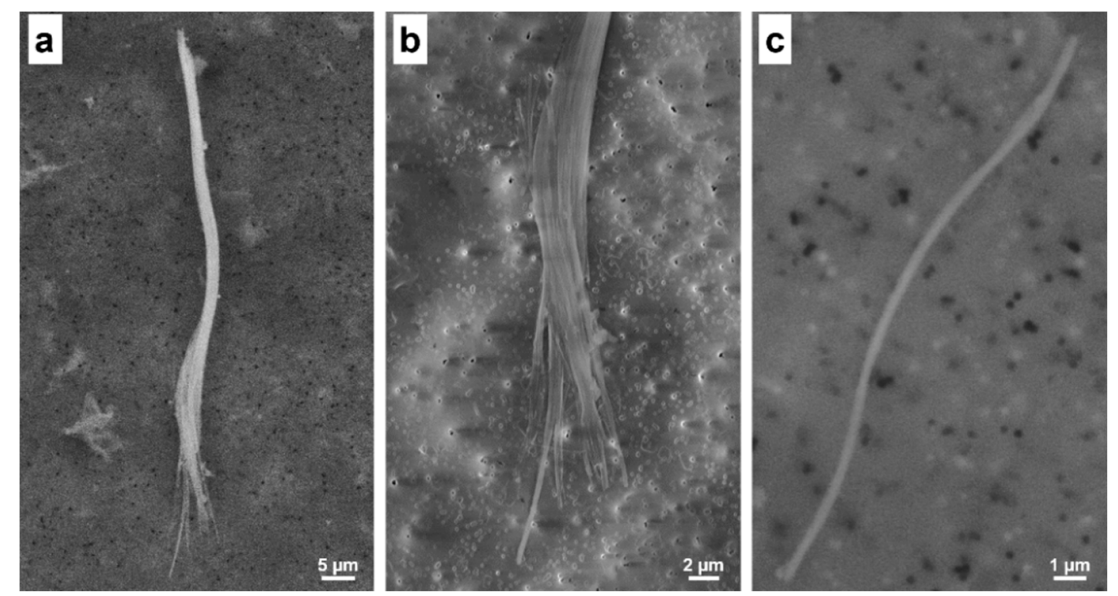

Figure 3. Fibers and bundles of fibers observed in digested neoplastic tissue. (a) Bundle of fibers observed in the neoplastic tissue. (b) Magnification of the top of the bundle, showing separation of the different fibers, as expected in the asbestos minerals. (c) Typical single fiber detected in the neoplastic tissue. 

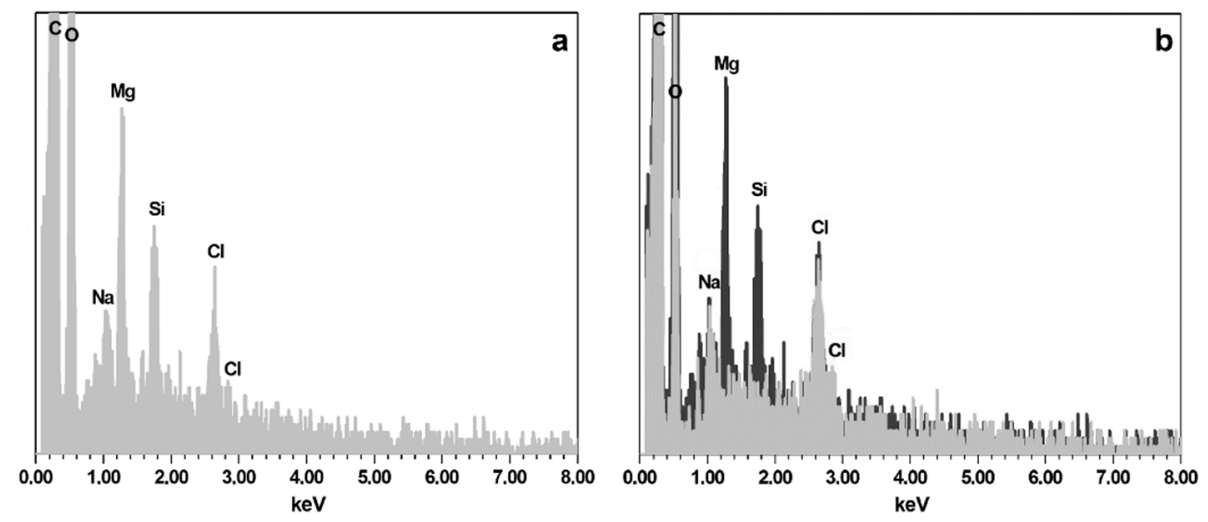

Figure 4. Characteristic chemical analyses obtained on the fibers of Figure 3. (a) Representative EDS spectrum recorded on the fibers in Figure 3a,c. The relative intensities of Mg and Si peaks identify chrysotile, a mineral regulated as asbestos. $\mathrm{Na}$ and $\mathrm{Cl}$ peaks are produced by $\mathrm{NaCl}$ crystallization during the digestion process. (b) Superimposition of the spectrum reported in (a) and the spectrum recorded in an area exterior to the fibers. The fiber is composed by $\mathrm{Si}$ and $\mathrm{Mg}$, with relative intensities allowing, together with the morphological features, identification of chrysotile.

Analysis of the neoplastic tissue, using the Equation (1) and counting the bundles of fibers as single fibers, yielded about $8 \times 10^{3} \mathrm{ff} / \mathrm{g}$.

In both healthy and neoplastic tissues, many small rounded formations, micro- and nanometric in size, were observed (Figure 5a). The EDS spectra, shown in Figure 5b, revealed a calcium phosphate composition, with small amounts of $\mathrm{Mg}$. This type of crystallizations was observed by Musa et al. [28] in the pleura of patients affected by mesothelioma and they were characterized by VP-SEM/EDS and micro-Raman techniques. Apatite, $\mathrm{Ca}_{5}\left(\mathrm{PO}_{4}\right)_{3}(\mathrm{OH})$, or, more frequently, a phase close to $\beta$-tricalcium phosphate, $\beta-\mathrm{Ca}_{3}\left(\mathrm{PO}_{4}\right)_{2}$ were identified as mineral phases. In the current study, $\mathrm{Mg}$ was detected as a minor component, giving the EDS spectrum shown in Figure $5 \mathrm{~b}$, but the mineral phase of the rounded formations cannot be, at the moment, surely established.
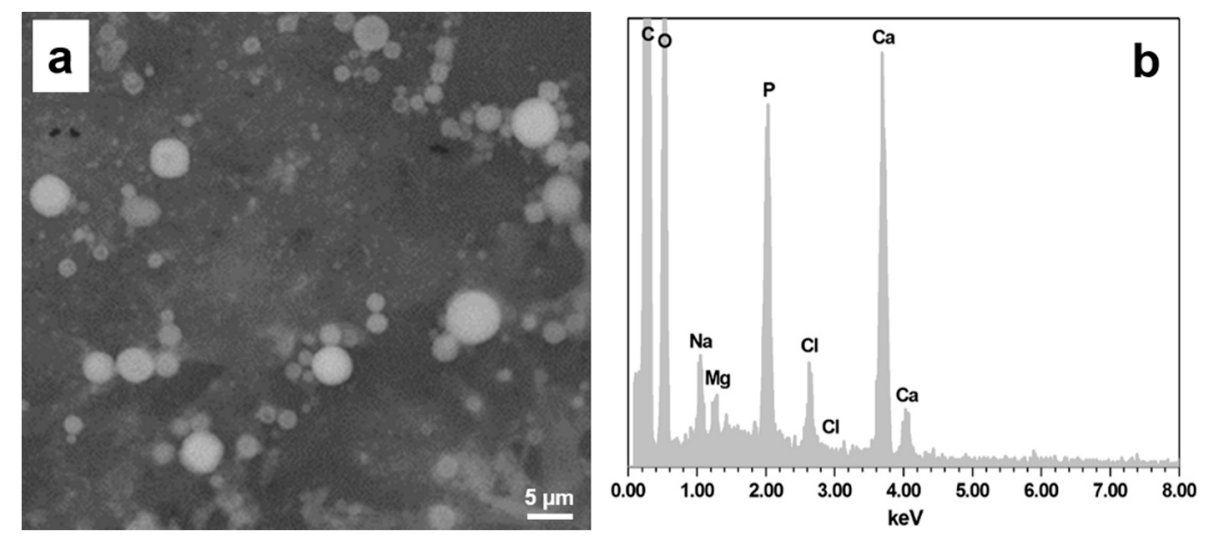

Figure 5. Rounded formations observed in the digested tissues. (a) Typical rounded crystallizations observed both in healthy and neoplastic digested tissues. (b) Typical EDS spectrum recorded on the crystallizations in (a), proving a calcium phosphate composition with small amounts of $\mathrm{Mg}$ substituting for calcium. $\mathrm{Na}$ and $\mathrm{Cl}$ peaks are ascribed to $\mathrm{NaCl}$ crystallization during the digestion process.

\subsection{Analysis of Thin Sections}

After analysis of filters after digestion of the biological matrix, three thin sections from the colon tissue of the same patient, prepared on a plastic support, were examined under VP-SEM/EDS. Only small individual fibers, not covered by iron-protein, were observed and on the basis of their EDS spectra confirmed as asbestos. An example is 
reported in Figure 6a, where the chemicals, $\mathrm{Si}, \mathrm{Mg}$ and $\mathrm{Ca}$ in the EDS spectrum, shown in Figure $6 \mathrm{~b}$, led to identification of tremolite, mineral phase regulated as asbestos. The morphological characteristics of the asbestos fibers detected in the histological sections and the corresponding mineral phase for each fibrous morphology are shown in Table 1.

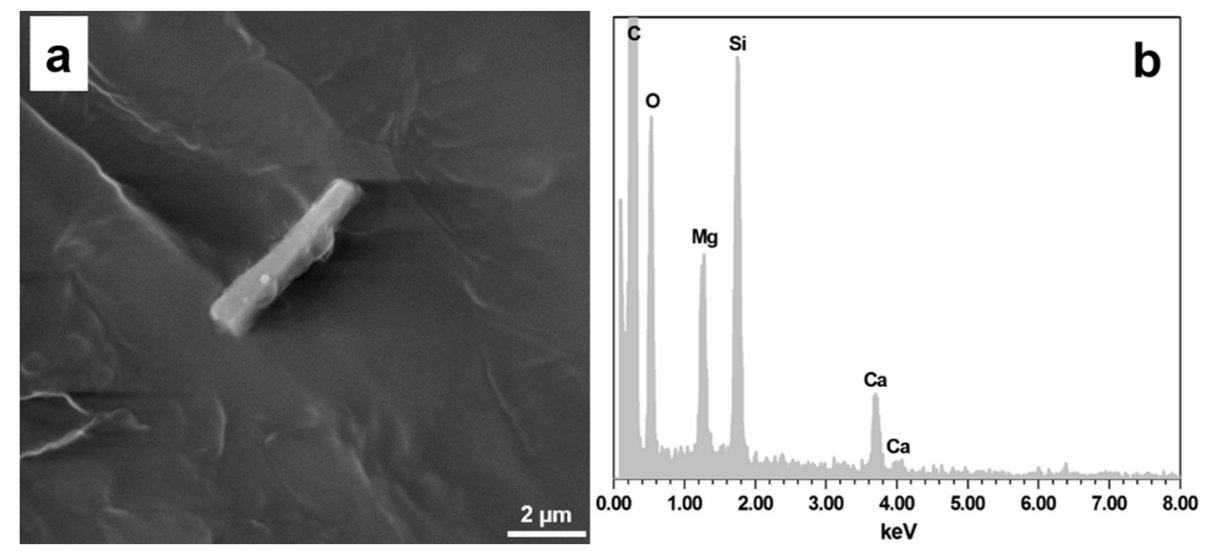

Figure 6. Fiber observed directly in a thin section and the relative EDS analysis. (a) Small fiber observed in thin section. (b) EDS spectrum collected on the fiber in (a) and identifying tremolite.

Table 1. Morphological characteristics and mineral phase of the fibers detected in the thin sections ( ${ }^{*}$ length/thickness ratio).

\begin{tabular}{ccccc}
\hline Sample & Mineral Phase of the Fiber & Length $(\boldsymbol{\mu m})$ & Thickness $(\boldsymbol{\mu m})$ & $\mathbf{1 / \mathbf { t } ^ { * }}$ Ratio \\
\hline \multirow{3}{*}{ Section 1 } & Tremolite & 4.81 & 0.98 & 4.91 \\
& Chrysotile & 7.28 & 1.42 & 5.13 \\
& Chrysotile & 5.62 & 1.12 & 5.02 \\
Section 2 & Tremolite & 11.53 & 1.75 & 6.59 \\
& Tremolite & 9.30 & 1.21 & 7.69 \\
Section 3 & Tremolite & 8.22 & 1.66 & 4.95 \\
& Chrysotile & 11.93 & 2.10 & 5.68 \\
& Chrysotile & 12.21 & 1.88 & 6.49 \\
\hline
\end{tabular}

One of the fibers exhibited a length shorter than $5 \mu \mathrm{m}$, which is the limit required for the definition of breathable fibers by WHO [24], but being outside the respiratory system, it has been considered. In fact, other mechanism than breathing may be in the studied case active.

The location and the areas surrounding the fibers detected under VP-SEM/EDS were recorded at increasing magnifications to identify the same areas on H\&E stained section. This last, examined under the Optical Microscope $(\mathrm{OM})$, allowed the pathologist to define the characteristics of the tissue in which the fibers were detected under VP-SEM/EDS. In the studied sections, the fibers described in Table 1 resulted in a percentage of about $67 \%$ lying in a strip of poorly differentiated neoplastic tissue near to the healthy one (central area in Figure 7). The tissue area was characterized by a cribriform growth (near point 1 in Figure 7), a tumoral island with vessels (points 2, 3, 4, and 5) and an area of poorly differentiated neoplastic tissue with a central necrosis (point 6). The other fibers were detected in the solid tumor tissue (points 7 and 8 in Figure 7). A fiber was observed in a submucosal tunica (point 9 in Figure 7). These data indicated that asbestos fibers were generally embedded in neoplastic tissue or in areas nearby in an amount of about $90 \%$. 


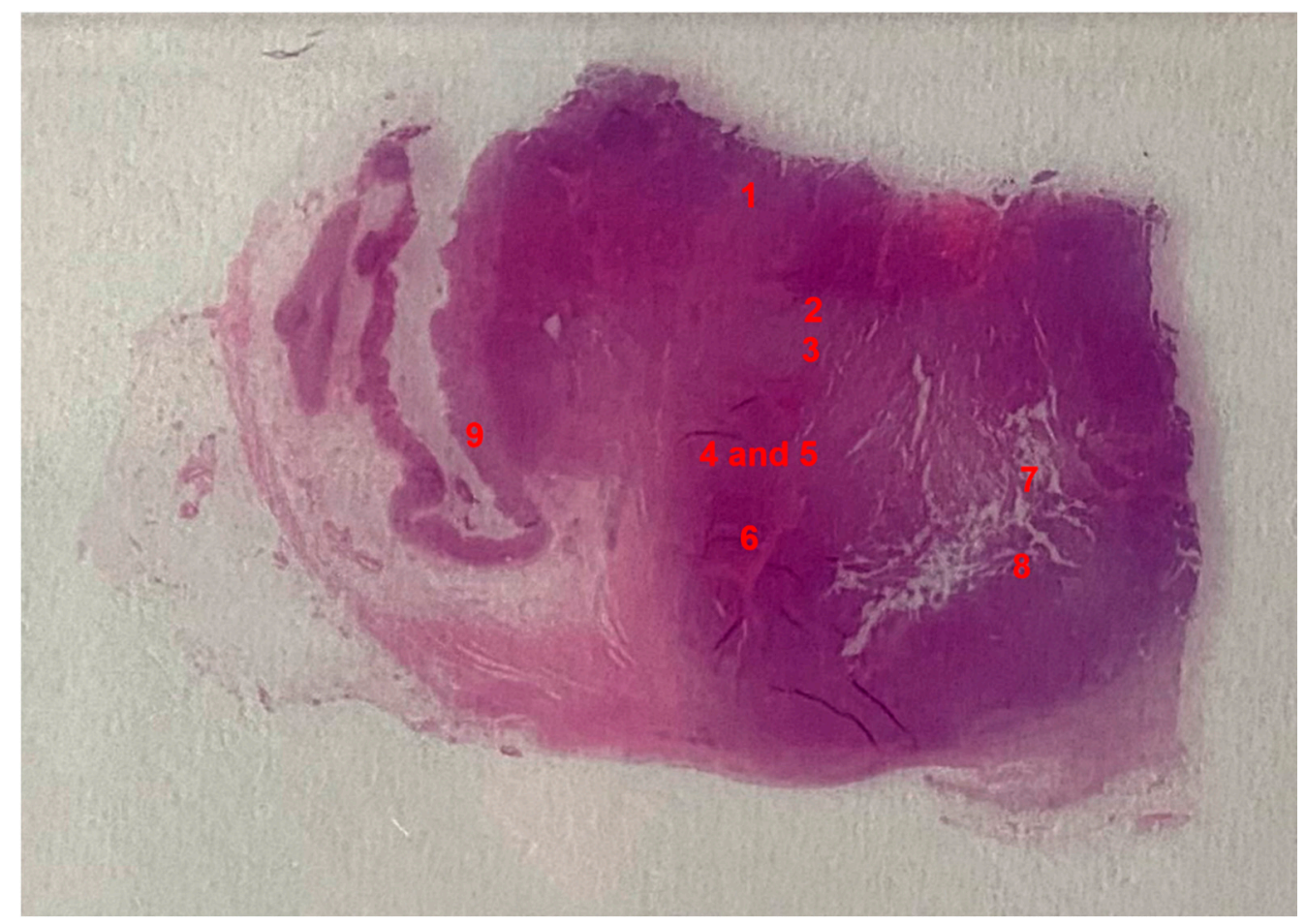

Figure 7. Stained section and localization of the fibers observed under VP-SEM/EDS. The numbers indicate the areas where the asbestos fibers were detected in the histological sections.

On all three thin sections, many rounded formations, as shown in Figure 5 and corresponding to calcium phosphate were observed.

\subsection{Immunohistochemical and Molecular Analyses}

Colon cancer progression is driving by many molecular mutations in epithelial tissue, responsible of oncogene constitutive activation. These mutations translate in the synthesis of constitutively activated proteins, sometimes responsible of tumor tissue transformation, through stimulation of mitotic proliferation and inhibition of programmed cellular apoptosis. Another mechanism underlying carcinogenesis involves inactivation of the DNA mismatch repair protein complex. This complex is composed of four nuclear proteins working in tandem to repair sporadic DNA mutations, incoming in somatic cycling cells during replication. Mutations of one protein of the complex can lead to disruption in DNA repair, leading to increased somatic DNA mutations, genetic instability and increased possibilities for un-controlled epithelial proliferation, absence of cellular apoptosis and tumoral progression.

Immunohistochemical investigation of mismatch repair proteins in the current case confirmed expression of the nuclear protein complex, responsible for DNA damage repair (Figure 8). Approximately one-third of colonic cancer cases show deletion or mutation of one or more of these proteins. The nuclear expression of all four proteins in tumoral tissue ruled out the possibility of microsatellite instability. We also investigated expression of the BRAF V600E point mutant, which leads to constitutive activation of the BRAF kinase, by immunohistochemical analysis. However, this sample did not show BRAF V600E expression. Negative result allowed to exclude that this colon cancer could be linked to the constitutive activation of the BRAF kinase. No mutations were detected in RAS genes through PCR technique, leading to the conclusion that the more frequent molecular mechanism responsible of colon carcinogenesis was not involved in the case considered in the present work. In the light of the data presented, fibers detected in the tumor tissue could have a role in the carcinogenesis. 

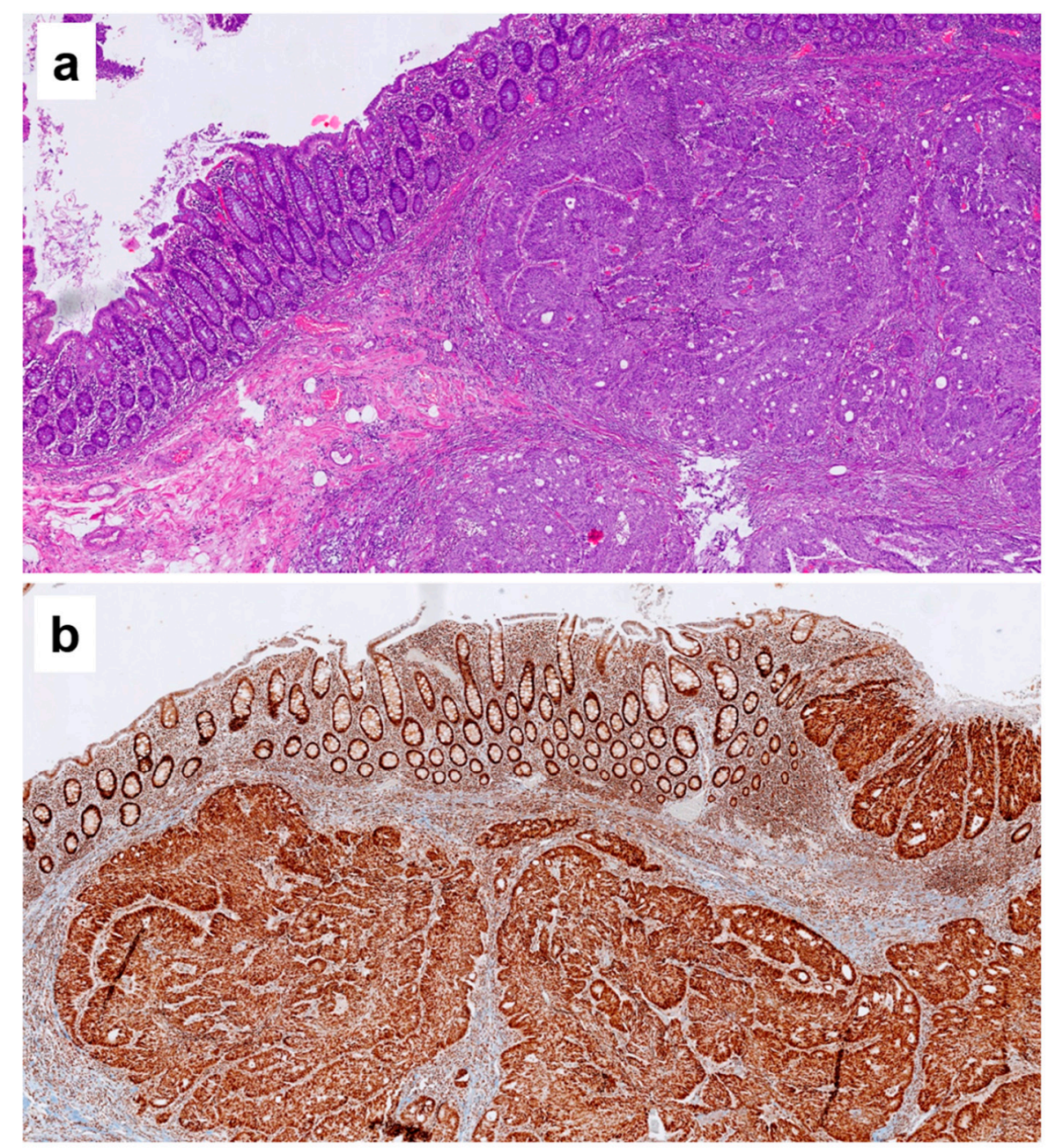

Figure 8. Immuno-histochemical analysis. (a) Solid cancer tumor in relation to normal glandular mucosa and corresponding to the area where fibers were observed (magnification $4 \times$ ). (b) IHC staining for MLH1 of the same area. Brown color indicates expression of the MLH1 nuclear protein. High expression in tumor cells indicates well-functioning mismatch repair protein complex.

\section{Discussion and Conclusions}

In this study, we examined, as case study, samples from a patient with colon cancer and with an indirect past exposure to asbestos to investigate the presence of asbestos fibers in the tissues removed during surgery. We used VP-SEM/EDS, which allowed morphological and chemical characterization of the fibers. In the healthy tissue, asbestos bodies, fibers covered by iron-proteins, and very short fibers were observed. Based on the chemical elements detected on the EDS spectra, amosite and tremolite/actinolite, minerals regulated as "asbestos" have been identified. The concentration of fibers/asbestos bodies was about $3 \times 10^{3} \mathrm{ff} / \mathrm{g}$.

In the neoplasia tissue, very long bundles of fibers or long fibers $(20-50 \mu \mathrm{m})$ of chrysotile, at a concentration of about $8 \times 10^{3} \mathrm{ff} / \mathrm{g}$, were observed. These fibers in the neoplastic tissue were free from covering.

Different pathways may be hypothesized for the fibers to reach the different analyzed tissues. As it concerns the asbestos bodies, they were commonly observed in the lung or in pleura of patients affected by mesothelioma, a disease with a very long time of latency (about 45 years) [29], and the covering around the fiber may be a time-consuming process. Certainly, it is a very active mechanism in the respiratory system, therefore the asbestos bodies observed in the healthy tissue of colon could actually be formed in the respiratory system. Other areas of the human body, the colon in the studied case, 
can be reached through translocation mechanism. In contrast, the free fibers detected in neoplastic area or near to it may be incorporated by mechanisms other than breathing, for example by the digestion process or by swallowing of bronchial mucus, as proposed by Ehrlich et al. [16,17].

It can be underlined that long fibers $(20-50 \mu \mathrm{m})$ were observed only after digestion of the tissue; the preparation of the thin sections $(5 \mu \mathrm{m})$ may facilitate, during the different steps, their ejection or cutting. Currently, this may be proposed for their absence in the examined thin sections.

The small asbestos fibers of chrysotile and tremolite detected in thin sections by VP-SEM/EDS appeared located in the region bridge between the healthy tissue and the neoplasia. Immunohistochemical investigations on the neoplastic tissue supported an active role of asbestos in the carcinogenesis mechanism.

Amosite and chrysotile fibers or asbestos bodies were observed by Ehrlich et al. in colon of asbestos-exposed workers but they never detected crocidolite, tremolite and anthophyllite [17]. In our case, fibers of amosite, chrysotile but also tremolite or tremolite/actinolite have been identified. This discrepancy may be linked to the type of asbestos containing materials to which the different patients were exposed.

The described results are certainly preliminary data, but they demonstrate the relevance of studies on a larger cohort of patients and we plan to pursue these investigations in the future.

Author Contributions: Conceptualization, C.R., F.G., S.E. and M.A.; methodology, C.R., A.C., E.N. and S.E.; software, A.C. and S.E.; validation, C.R., S.E. and M.A.; formal analysis, C.R., A.C., E.N. and S.E.; investigation, C.R., A.C. and M.A.; resources, C.R., S.E. and F.G.; data curation, C.R., A.C., E.N. and S.E.; writing-original draft preparation, C.R. and S.E.; writing-review and editing, C.R. and A.C.; visualization, C.R. and A.C.; supervision, C.R., M.A. and A.M.; project administration, M.A., M.B. and C.R.; funding acquisition, C.R. and F.G. All authors have read and agreed to the published version of the manuscript.

Funding: This research was funded by ASL AL ("Progetto globale di ricerca in tema di cure e di prevenzione per la diagnosi e la terapia del mesotelioma-CUP C68F14000270005") and by CRT ("Identification and quantification of asbestos fibers in tissues from patients affected by colon cancer").

Institutional Review Board Statement: The case study was conducted according to the guidelines of the Declaration of Helsinki, and approved by the Scientific Committee of SS Antonio e Biagio e Cesare Arrigo, General Hospital (date of approval 1 October 2019).

Informed Consent Statement: Informed consent was not necessary being the samples anonymized.

Data Availability Statement: The data presented in this study are available in the article.

Acknowledgments: The authors wish to thank Anthony Simoniello for his work in the digestion of the biological samples and Gabrielle White Wolf, from Edanz Group (https: / en-author-services. edanz.com/ac (accessed on 29 March 2021)) for editing a draft of this manuscript and the two anonymous referees for their suggestions.

Conflicts of Interest: The authors declare no conflict of interest.

\section{References}

1. Guthrie, G.D.; Mossman, B.T. Health effects of mineral dusts. In Reviews in Mineralogy; Guthrie, G.D., Mossman, B.T., Eds.; Mineralogical Society of America: Washington, DC, USA, 1993; p. 28, ISBN 0-939950-33-2.

2. Brody, A.R. Asbestos-induced lung disease. Environ. Health Perspect. 1993, 100, 21-30. [CrossRef]

3. Kane, A.B.; Kumar, V. Environmental and nutritional pathology. In Robbins Pathologic Basis of Disease, 6th ed.; Cotran, R.S., Kumar, V., Collins, T., Eds.; Saunders W.B. Company: Philadelphia, PA, USA, 1999; pp. 403-458.

4. Bartrip, P.W.J. History of asbestos related disease. Postgrad. Med. J. 2004, 80, 72-76. [CrossRef]

5. Carbone, M.; Bedrossian, C.W. The pathogenesis of mesothelioma. Semin. Diagn. Pathol. 2006, 23, 56-60. [CrossRef]

6. Gunter, M.E.; Belluso, E.; Mottana, A. Amphiboles: Environmental and health concerns. In Reviews in Mineralogy and Geochemistry; Rosso, J.J., Ed.; Mineralogical Society of America: Chantilly, VA, USA, 2007; Volume 67, pp. 453-516. [CrossRef] 
7. Yang, H.; Rivera, Z.; Jube, S.; Nasu, M.; Bertino, P.; Goparaju, C.; Franzoso, G.; Lotze, M.T.; Krausz, T.; Pass, H.I.; et al. Programmed necrosis induced by asbestos in human mesothelial cells causes high-mobility group box 1 protein release and resultant inflammation. Proc. Natl. Acad. Sci. USA 2010, 107, 12611-12616. [CrossRef]

8. Carbone, M.; Ly, B.H.; Dodson, R.F.; Pagano, I.; Morris, P.T.; Dogan, U.A.; Gazdar, A.F.; Pass, H.I.; Yang, H. Malignant mesothelioma: Facts, myths, and hypotheses. J. Cell. Physiol. 2012, 227, 44-58. [CrossRef]

9. Comertpay, S.; Pastorino, S.; Tanji, M.; Mezzapelle, R.; Strianese, O.; Napolitano, A.; Baumann, F.; Weigel, T.; Friedberg, J.; Sugarbaker, P.; et al. Evaluation of clonal origin of malignant mesothelioma. J. Transl. Med. 2014, 12, 301. [CrossRef] [PubMed]

10. Grosso, F.; Randi, L.; Croce, A.; Mirabelli, D.; Libener, R.; Magnani, C.; Bellis, D.; Allegrina, M.; Bertolotti, M.; Degiovanni, D.; et al. Asbestos fibers in the gallbladder of patients affected by benign biliary tract diseases. Eur. J. Gastroenterol. Hepatol. 2015, 27, 860-864. [CrossRef] [PubMed]

11. Grosso, F.; Croce, A.; Trincheri, N.F.; Mariani, N.; Libener, R.; Degiovanni, D.; Rinaudo, C. Asbestos fibres detected by scanning electron microscopy in the gallbladder of patients with malignant pleural mesothelioma (MPM). J. Microsc. 2017, 266, 48-54. [CrossRef]

12. Croce, A.; Capella, S.; Belluso, E.; Grosso, F.; Mariani, N.; Libener, R.; Rinaudo, C. Asbestos fibre burden in gallbladder: A case study. Micron 2018, 105, 98-104. [CrossRef] [PubMed]

13. Grosso, F.; Croce, A.; Libener, R.; Mariani, N.; Pastormerlo, M.; Maconi, A.; Rinaudo, C. Asbestos fiber identification in liver from cholangiocarcinoma patients living in an asbestos polluted area: A preliminary study. Tumori J. 2019, 105, 404-410. [CrossRef]

14. International Agency for Research on Cancer (IARC). Asbestos (chrysotile, amosite, crocidolite, tremolite, actinolite, and anthophyllite). In IARC Monographs on the Evaluation of Carcinogenic Risks to Humans; IARC: Lyon, France, 2012; Volume 100C, pp. 219-309, ISBN 978-92-832-1320-8.

15. Gamble, J.F. Asbestos and colon cancer: A weight-of-the-evidence review. Environ. Health Perspect. 1994, 102, 1038-1050. [CrossRef] [PubMed]

16. Ehrlich, A.; Rohl, A.N.; Holstein, E.C. Asbestos bodies in carcinoma of colon in an insulation worker with asbestosis. JAMA 1985, 254, 2932-2933. [CrossRef]

17. Ehrlich, A.; Gordon, R.E.; Dikman, S.H. Carcinoma of the colon in asbestos-exposed workers: Analysis of asbestos content in colon tissue. Am. J. Ind. Med. 1991, 19, 629-636. [CrossRef]

18. Kobayashi, H.; Ming, Z.W.; Watanabe, H.; Ohnishi, Y. A quantitative study on the distribution of asbestos bodies in extrapulmonary organs. Acta Pathol. Jpn. 1987, 37, 375-383. [CrossRef] [PubMed]

19. Rinaudo, C.; Gastaldi, D.; Belluso, E. Characterization of chrysotile, antigorite and lizardite by FT-Raman spectroscopy. Can. Mineral. 2003, 41, 883-890. [CrossRef]

20. Rinaudo, C.; Belluso, E.; Gastaldi, D. Assessment of the use of Raman spectroscopy for the determination of amphibole asbestos. Miner. Mag. 2004, 68, 455-465. [CrossRef]

21. Groppo, C.; Rinaudo, C.; Cairo, S.; Gastaldi, D.; Compagnoni, R. Micro-Raman spectroscopy for a quick and reliable identification of serpentine minerals from ultramafics. Eur. J. Mineral. 2006, 18, 319-329. [CrossRef]

22. Bloise, A.; Critelli, T.; Catalano, M.; Apollaro, C.; Miriello, D.; Croce, A.; Barrese, E.; Liberi, F.; Piluso, E.; Rinaudo, C.; et al. Asbestos and other fibrous minerals contained in the serpentinites of the Gimigliano-Mount Reventino Unit (Calabria, S-Italy). Environ. Earth Sci. 2014, 71, 3773-3786. [CrossRef]

23. Croce, A.; Musa, M.; Allegrina, M.; Trivero, P.; Rinaudo, C. Environmental scanning electron microscopy technique to identify asbestos phases inside ferruginous bodies. Microsc. Microanal. 2013, 19, 420-424. [CrossRef]

24. World Health Organization (WHO). Environmental Health Criteria 53-Asbestos and Other Natural Mineral Fibres; International Programme for Chemical Safety: Geneva, Switzerland, 1986; ISBN 92-4-154193-8.

25. Chasteen, N.D.; Harrison, P.M. Mineralization in ferritin: An efficient means of iron storage. J. Struct. Biol. 1999, 126, 182-194. [CrossRef]

26. Kim, S.-W.; Seo, H.-Y.; Lee, Y.-B.; Park, Y.-S.; Kim, K.-S. Crystal structure of ferrihydrite nanoparticles synthesized in ferritin. Bull. Korean Chem. Soc. 2008, 29, 1969-1972. [CrossRef]

27. Belluso, E.; Bellis, D.; Fornero, E.; Capella, S.; Ferraris, G.; Coverlizza, S. Assessment of inorganic fibre burden in biological samples by scanning electron microscopy-Energy dispersive spectroscopy. Microchim. Acta 2006, 155, 95-100. [CrossRef]

28. Musa, M.; Croce, A.; Allegrina, M.; Rinaudo, C.; Belluso, E.; Bellis, D.; Toffalorio, F.; Veronesi, G. The use of Raman spectroscopy to identify inorganic phases in iatrogenic pathological lesions of patients with malignant pleural mesothelioma. Vib. Spectrosc. 2012, 61, 66-71. [CrossRef]

29. Marinaccio, A.; Binazzi, A.; Cauzillo, G.; Cavone, D.; De Zotti, R.; Ferrante, P.; Gennaro, V.; Gorini, G.; Menegozzo, M.; Mensi, C.; et al. Analysis of latency time and its determinants in asbestos related malignant mesothelioma cases of the Italian register. Eur. J. Cancer 2007, 43, 2722-2728. [CrossRef] [PubMed] 